
8 Research Square

\title{
Geographical rang evolution of whipping frogs based on a phylogeny of genus Polypedates (Anura: Rhacophoridae)
}

\section{Xiling Deng}

Institute of Qinghai-Tibetan Plateau, Southwest Minzu University

\section{Limei Yuan}

Institute of Qinghai-Tibetan Plateau, Southwest Minzu University

\section{Kong Yang}

Institute of Qinghai-Tibetan Plateau, Southwest Minzu University

\section{Sebastian Klaus}

Dept. of Ecology and Evolution, J.W. Goethe-Universit

Nikolai L. Orlov

Zoological Institute, Russian Academy of Sciences

Dechun Jiang ( $\square$ jiangdc@cib.ac.cn )

Chengdu Institute of Biology, Chinese Academy of Science

Jia-Tang Li

Chengdu Institute of Biology, Chinese Academy of Science

\section{Research}

Keywords: The Polypedates; dispersal time calibration; Southeast Asia

Posted Date: January 1st, 2020

DOl: https://doi.org/10.21203/rs.2.19846/v1

License: (c) (i) This work is licensed under a Creative Commons Attribution 4.0 International License. Read Full License 


\section{Abstract}

Background The genus Polypedates has a wide range, covering eastern India, Southeast Asia, South China, and eastward to the Philippines and Japan. Because of their poor marine dispersal capabilities, they are ideal organisms to infer geological and environmental history. Based on a large amount of data set for the genus Polypedates that we compiled from a dozen previous studies and partial mitochondrial and nuclear genes collected in this study, we calculated thorough statistical biogeographical analyses. Results We can confirm the genus' Sundaland origin and showed its northward dispersal into Indochina and mainland Asia from the Late Oligocene to Middle Miocene. And the Red River did not mediate species exchange between Southeast Asia and mainland Asia until the end of the Miocene, with a sudden onset of northward dispersal in several clades independently at that time. The widespread P. leucomystax dispersed from Indochinese Peninsula southward to Malay Peninsula, Sumatra and Java, afterwards to Borneo and Sulawesi. Our biogeographical analysis supports the view of a recent introduction of P. leucomystax to the Philippines and the Ryukyus as previously suggested. Conclusion Our results indicate that climate fluctuations have a profound impact on species diversification within genus Polypedates . The Red River did not act as a diffuse filter barrier for the species exchange until the end of the Miocene. And the widespread P. leucomystax dispersed in Southwest possibly facilitated by the freshwater plume of the emergent South Sunda River System.

\section{Background}

The genus Polypedates (Rhacophoridae) [1], also known as whipping frogs [2], has a widespread occurrence, covering eastern India, Southeast Asia, South China, and eastward to the Philippines and Japan [3]. It has in common with several other species of the genera Chiromantis and Rhacophorus that it can resist desiccation and shows a characteristic reproductive trait in that the females lay a foamy egg nest on or near water [4]. This indicates that albeit being dependent on the presence of forest and rainfall, Polypedates has good surviving skills under unfavourably dry conditions which likely facilitated the colonization of its wide range.

During the last decades, research on this genus mostly concentrated on the molecular phylogenetic relationships among Polypedates species, and particularly on the taxonomic study of Polypedates leucomystax species complex [5-10]. Kuraishi et al. [4] conducted a comprehensive phylogenetic study of the P. leucomystax complex based on both mtDNA and nuDNA, and including divergence time estimation, but with a limitation of biogeographic patterns analysis. Polypedates species were once regarded as extraordinary widely distributed from India to eastern Indonesia [11-13]. But after a long time of taxonomic confusion, reclassification of the genus led to the exclusion of P. mutus, P. impresus, P. braueri and P. megacephalus in south China [8] and Taiwan [14]. Brown et al. [5] suggested recent population expansion of P. leucomystax complex in Philippines and Sulawesi. This leads to the hypothesis that human-mediated dispersal between oceanic islands. Kuraishi et al. [15] investigated the origin of P. leucomystax on the Ryukyus, also concluding that this was facilitated by accidental human transport from Southeast Asia. Blair et al. [16] published a study on the evolutionary history of the P. 
leucomystax in south China and on the Indochinese Peninsula including estimation of divergence times and population genetic analyses, which suggested a northern origin and southward dispersal. Their result refuted that the demographic expansion of this species and the wide spread sympatry of lineages originated from human-mediated dispersal between insular and mainland populations, and found the Red River as a partial barrier for gene flow. Buddhachat et al. [6] revealed allopatric and sympatric speciation under climatic pressure in P. leucomystax complex. However, samples of these studies were only from Sunda Islands or Indochina mainland. A complete biogeographic study for the genus Polypedates is still unavailable.

As a widely distributed treefrog group, the genus Polypedates occupied in south China, India, most islands of Southeast Asia and Japan. And their current distribution area includes the biodiversity hotspots of Himalayas, Hengduan Mountains, Indo-Burma, Sundaland, part of Wallacea and Philippines [17]. From previous research, it manifested that this genus diversed from Oligocene [18], and remains to be genetic divergence in the very close recent. Therefore, it seems to be that the dispersal process of Polypedates is in the wake of paleotectonism and paleoclimate events such as the Indian-Eurasian collision, the uplift of Himalayas, and the Pleistocene sea-level fluctuations from glacial and interglacial. It is still necessary to present convincing evidence based on previous achievement to make clear how geological events affected the evolution of these frogs, meanwhile mediately verify when the geological events occurred with the time estimate of the living Polypedates.

Here we compiled a large data set of currently recognized species within the genus Polypedates from the literature and partial mitochondrial and nuclear genes collected in this study to (1) investigate its phylogenetic relationships, reinterpreted the distribution of each species particularly P. leucomystax, (2) reveal the origin and dispersal history of Polypedates on the regions based on divergence time estimation and inference of ancestral areas, and (3) test the effects of paleotectonism and paleoclimate events on diffusion of genus Polypedates.

\section{Results}

\section{Phylogenetic analyses and divergence time estimates}

Both Maximum Likelihood and Bayesian phylogenetic inference resulted are consistent (Fig. 1 and Additional file 1: Fig. S1). Each major clade was strongly supported in both analyses. The species P. cruciger, P. maculatus and P. pseudocruciger which are all from India belong to the same clade with high support. Most species contained in P. leucomystax complex such as P. macrotis, P. mutus, P. braueri, P. impresus, and P. megacephalus clades were strongly supported as valid species. Species dispersal between India and other place happened twice, once with the species P. cruciger, P. maculatus and P. pseudocruciger, and once with the species P. teraiensis (Fig. 2).

The divergence time estimate for the root of Polypedates and the genera Feihyla, Ghatixalus and Taruga (the clade comprising samples 1-119) is dated to early Oligocene with a $95 \%$ highest posterior density 
interval (HPD) of 37-29 Myr, and the genus Polypedates starts to diversify from the early Miocene onwards (samples17-119, 95\% HPD 26-19 Myr).

\section{Biogeography analysis}

The two biogeographical analyses methods equally support a Sunda islands origin for the genus Polypedates (Fig. 2). However, more precisely, we could infer as the most likely scenario that P. otilophus and the MRCA of the remaining Polypdates species origined at around $22 \mathrm{Myr}(26-19 \mathrm{Myr})$. The MRCA of samples 34-119 spread to Indochina (south of the Red River) during the late Miocene (at 14-8 Myr) and subsequently dispersed to China, specifically within P. mutus, P. braueri, and P. megacephalus. During the Late Miocene to Pliocene (6-3 Myr) there was a back dispersal from Indochina to Sundaland within the MRCA of P. leucomystax, and to India during the Pliocene to Pleistocene (3-1 Myr) within P. teraiensis. Dispersed to the Philippines two times, once within P. macrotis that diverged in Borneo and then dispersed to the Philippines during Late Miocene to Pleistocene (6-1 Myr). Most likely this species entered the Philippines via an 'eastern-arc colonization' [19] which was abled from middle Oligocene to early Pliocene [20]. P. leucomystax dispersed to the Philippines very recently (Holocene); subsequently reaching Japan.

The MRCA P. leucomystax dated to the late Miocene and early Pliocene (95\% HPD 6-3 Myr) with an ancestral range comprising Malay Peninsula, Sumatra and Java (Fig. 3). In a very recent epoch P. leucomystax (samples 86-101) showed high gene flow between Borneo and the Malay Peninsula. The spread of P. leucomystax from Java to Sulawesi was detected only once, but to Sumatra twice, firstly from Indochina and second from Java. The Philippines' samples (104 and 106) along with the Japanese samples (105 and 107) nested within the Java clade, indicating that P. leucomystax in of the Philippines originated from Java and subsequently dispersed to Japan.

\section{Discussion}

Late Oligocene to Early Miocene origin of the Polypedates.

Amphibians are often considered excellent model system for biogeographic studies on overseas dispersal events [18, 19, 21-27]. Many biogeographic studies suggested Southeast Asia is a cradle for amphibian speciation $[21,22,25,26]$. In this study, the phylogenetic analyses supported the sister relationship of Taruga and Polypedates. Taruga eques and Taruga fastigo were accommodated by Meegaskumbura et al. [28]. As Taruga in this study occurred in India and Rhacophoridae definitely origined in India [18], it can be inferred that the MRCA of genus Taruga and Polypedates originated from India. However, the biogeographical analyses of the present, compiled data set confirm Sundaland as the origin of the genus Polypedate, with subsequent dispersed to Indochina (Fig. 2). These patterns elucidated that the MRCA of genus Polypedates diverged from the MRCA of genus Taruga probably in Sundaland, and differentiation dispersed to more northern regions, which in line with Kuraishi et al. [4]. On this occasion, the lineages from India in genus Polypedates should be considered further. Although locality specimens and sequences from India are lack in this study, it can be inferred that dispersal 
between India and Southeast Asia does not seen to be only once. P. cruciger, P. maculatus, and P. pseudocruciger dispersed from Sundaland to India (19-11 Myr) first time, coincided with the global Mid Miocene Climatic Optimum [29]. And P. teraiensis dispersed in sympatric regions in Indochina and India second time. Additionally, cryptical species distributed in India might indicate ancestor dispersal from India to Southeast Asia, such as other species [18, 30-32], which would change the original biogeographical history of genus Polypedates. Additional sampling from India is required to test these predictions.

\section{Colonization from South to North}

After originated in Sundaland, genus Polypedates colonized into the Indochina (14-8 Myr) and then dispersed northward to mainland Asia during the Pliocene and Pleistocene. During these periods, genus Polypedates underwent range expansions at different times. Similarity, a recent study of genus Leptobrachella, which is also distributed in Southeast Asia, showed that range expansions from Sundaland to mainland Aisa occurred in this genus from Mid-Miocene to Pliocene [21]. Hughes et al. [33] suggested the Isthmus of Kra unlikely to be significant biogeographical boundaries, and also indicated the climate zone in Indochina during Last Glacial Period is the explanation for species distinct distribution. We assumed that genus Polypedates expanded Indochina from Sundaland, leading to diversification of species, under the influence of climate changes.

During the Middle Miocene, no divergence could be detected between the Indochina (i.e., southwest of the Red River) and South China (i.e., northeast of the Red River). The Red River zone has a complex geological history $[34,35]$. The formation of the Red River between southern China and northern Vietnam, initiated at $27 \mathrm{Myr}$ and terminated locally at about $21 \mathrm{Myr}$, not exceeding $17 \mathrm{Myr}$ [36-38], which could act potential geographic barriers for species dispersal. During this period, tectonic movements did not cause species divergence. As many taxa occur only one side of the Red River (such as Sophora davidii in Fan et al. [39]), we could hypothesise that change in the runoff regime might have caused a stronger isolation effect of the Red River by then, with the reservation that a denser population genetic sampling of the respective species will be necessary to draw sound conclusions.

Several times right-lateral strike-slips followed during late Miocene (12-9 Myr, 8-6 Myr) [40], which coincided with divergences across the Red River within the species P. mutus, P. braueri and P. megacephalus. Our result of the unencumbered of the Red River from late Miocene to early Pliocene for the genus Polypedate was similarity to the viewpoint from Blair et al. [16], whereas it consummated his consequence with a more larger dataset. Blair et al. [16] found that the Red River forms a partial barrier for some lineages and cannot explain the overall pattern, most likely due to the indistinct taxonomy of P. leucomystax and a circumscribed lineage divide. In the view of several studies showed genetic diversification between species on both side of the Red River [41, 42], Red River zone might conceivably function as diffuse filter barriers for the genus Polypedates.

Range evolution throughout oceanic islands within P. leucomystax. 
From early Pliocene till Holocene, P. leucomystax dispersed back to Sundaland from the Indochina (Fig. 2) and spread to the Malay Peninsula, the Greater Sunda Islands, the Philippines and to Japan (Fig. 3). The north-to-south dispersal pattern was also consistent with a genealogy and demographic analysis [16]. Not surprising, P. leucomystax shows considerable genetic differentiation across its vast range, in line with previous studies [5]. In view of the peculiar paleoclimate and tectonics through the continent of Sundaland and nearby area in Pleistocene [43], the wide spread of P. leucomystax might be driven by eustatic sea-level fluctuations. The high gene flow between Borneo and the Malay Peninsula samples conformed to the contiguous terrestrial areas resulted from glaciation. The Pleistocene colonization of Sulawesi from Java, despite the absence of a continuous land connection between Sulawesi and Sundaland [44], is not surprising and fits to the frequent dispersal across Wallace's line in other organisms including freshwater crabs, frogs, reptiles and mammals [45]. Possibly, the freshwater plume of the South Sunda River System enabled dispersal on driftwood from Java to Sulawesi during an eustatic sea-level lowstand, as hypothesised for freshwater crabs [46].

P. leucomystax spread to the Philippines from Java and then reached Japan close to the Holocene. Considering the massive distance and biogeographical barriers for amphibians that make a natural dispersal scenario highly unlikely, we support the hypotheses that transportation of agricultural products between islands facilitated the range expansion of P. leucomystax to the Philippines [5] and that accidental transport of few individuals with military cargo from somewhere around the Philippines established the populations on the Ryukyus as suggested by Kuraishi et al. [15]. We can not reject the hypothesis that Pleistocene sea-level dynamics have effects on the diversification of this species as an explanation for the range expansion with P. leucomystax. However, further evidence is required to address this possibility.

\section{Conclusions}

Over all, our skyline analyses revealed the evolutionary history of the genus Polypedates. The genus Polypedates mostly originated in insular Southeast Asia during the Late Oligocene. In the process of northward dispersal, climate changes influenced expansion and species diversification from Sundaland to Indochina. The Red River did not act as a diffuse filter barrier for the species exchange until the end of the Miocene. Since the early Pliocene P. leucomystax dispersed all over the Sundaland with Java as a source area. Our results make an effort to the combination of tectonics and climate changes and biological evolution with the genus Polypedates, corroborate the hypothesis about climate changes during Last Glacial Period and Red River fault zone with other fauna and flora. We also expect more samples from India to enrich the database, which may rewrite the biogeographic explanation within this group.

\section{Materials And Methods}

\section{Taxon Sampling, Data Collection and Geographic sampling}


Our dataset included 13 species of Polypedates (P.otilophus, P. colletti, P. cruciger, P. maculatus, P. pseudocruciger, P. macrotis, P. mutus, P. braueri, P. impresus, P. megacephalus, P. teraiensis, P. leucomystax, P. discantus), and additional 8 speciesbelonging to the genera Feihyla, Ghatixalus and Taruga that are closely related [18], and two outgroup species (Kurixalus idiootocus, Kurixalus banaensis) (see Additional file 1: Table S1). The sampling localities covered most of the distribution areas, including India, Sri Lanka, South China (including Hainan Island and Taiwan), Indochina (Vietnam, Laos, Thailand, Myanmar, Bangladesh) and Malay Peninsula with associated islands, Sundaland (Borneo, Java, Sumatra and Sulawesi), and the Philippine archipelago, as well as Japan (Fig. 4).

\section{DNA extraction, PCR amplifications and sequencing}

In order to researching the genus Polypedates, candidate DNA fragments, including three mtDNA and three nuclear DNA for 15 individuals from 6 species were newly acquired in this study. Genomic DNA was extracted from either muscle, or liver tissues initially preserved in either $95 \%$ ethanol. The Ezup Column Animal Genomic DNA Purification Kit (Sangon Biotech, China) was used for genomic DNA extraction following minor modifications to the manufacturer's protocol. We amplified and sequenced mitochondria gene (12S rRNA, tRNA ${ }^{\mathrm{Val}}$ and 16S rRNA) and three nuclear gene fragments with the indicated primer pairs, including proopiomelanocortin (POMC), Exon 1 of tyrosinase (RHOD) and exon 1 of tyrosinase (TYR) (Additional file 1: Table S2). Double stranded polymerase chain reaction (PCR) amplifications were

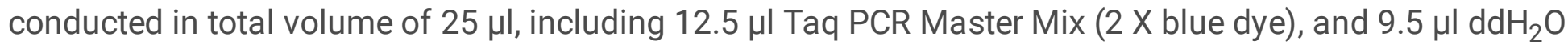
and $1 \mu \mathrm{l} \mathrm{FS01}$ and $1 \mu \mathrm{l}$ Rend $(\mathrm{C}=10 \mu \mathrm{l} / \mathrm{L})$, and $1 \mu \mathrm{LNA}$ templat. Cycle conditions for mitochondrial DNA were an initial denaturation of $3 \mathrm{~min}$ at $95^{\circ} \mathrm{C}$, followed by $94^{\circ} \mathrm{C}$ denaturation for $1 \mathrm{~min}, 55^{\circ} \mathrm{C}$ annealing for $1 \mathrm{~min}$, and for $1 \mathrm{~min}$ extension at $72^{\circ} \mathrm{C}$. Final extension at $72^{\circ} \mathrm{C}$ was conducted for $10 \mathrm{~min}$. For TYR, $\mathrm{RHOD}$, and POMC, the same procedure as for mitochondrial DNA was used, but with annealing at 56,52 , and $52^{\circ} \mathrm{C}$, respectively.

Other Sequences were retrieved from GenBank and originated from previous studies [4, 5, 8, 18, 47-55]. Alignments of all gene fragments were assembled in MEGA7 [56], and recheck in MAFFT version 7 [57], then adjusted manually resulting in lengths of $923 \mathrm{bp}$ for the $12 \mathrm{~S}$ rRNA gene, $74 \mathrm{bp}$ for tRNA ${ }^{\mathrm{Val}}, 1468 \mathrm{bp}$ for 16S rRNA, $532 \mathrm{bp}$ for TYR, $316 \mathrm{bp}$ for RHOD and $571 \mathrm{bp}$ for POMC. All sequences collected in this study have been deposited in GenBank under accession numbers (Additional file 1: Table S1).

\section{Phylogenetic Analyses}

The best partitioning scheme and model selection were estimated with PartitionFinder 2 [58] based on the Bayesian Information criterion. The data set was accordingly partitioned into two, a mitochondrial (12S rRNA gene, tRNAval ${ }^{\text {va }}$ 16S rRNA gene) and a nuclear (TYR, RHOD, POMC) partition. And the best fitting substitution model was $G T R+I+G$ for the mitochondrial and TRNEF $+I+G$ for the nuclear partition. We used two methods to construct phylogenetic trees, including Bayesian inference (BI) and maximumlikelihood (ML). BI was implemented in MrBayes 3.2.0 [59], the following settings were applied: number of Markov chain Monte Carlo $(\mathrm{MCMC})$ generations $=5000000$ and sampling frequency $=100$. The first 
12500 sampled trees were discarded as a conservative burn-in. ML phylogeny of the concatenated mitochondrial and the nuclear partition was calculated using RAxML 8.2.10 [60] under a GTR + Gamma model with 1000 bootstrap replicates; switching to the per-site rate category model.

\section{Divergence time estimation}

We used BEAST 2.5 [61] to estimate both a phylogenetic tree and divergence times. Site models were estimated with jModelTest 2.1.6 [62] based on the Akaike information criterion. And the best fitting substitution model was GTR + I + G for the mitochondrial and SYM + I + G for the nuclear partition. Few stratigraphic events can be associated with the divergence of species in Polypedates. Consequently, in the light of previously published data [18], we implemented second calibration points for the most recent common ancestor of Polypedates, Feihyla, Ghatixalus and Taruga, implemented as a Normal calibration density (Mean = 34.8, Sigma = 2.3) and the divergence point between genus Polypedates and Taruga, implemented as a Normal calibration density (Mean $=24$, Sigma $=2.1$ ). We applied a relaxed uncorrelated lognormal clock and a Yule tree prior. The analysis was repeated two times for 50 million generations separately, sampling every 5000th iteration on CIPRES Science Gateway (https:

//www.phylo.org/portal2/login). We checked for stationarity of the Markov chain and potential autocorrelation (effective sample sizes > 200 for all sampled parameters) in Tracer v1.6 [63]. The first $25 \%$ of samples were discarded as burn-in, and the samples of both runs combined in LogCombiner v2.5. This file was used in TreeAnnotator v2.5 to identify and annotate the maximum clade credibility tree. Given the inherent uncertainty of divergence time estimates, we rounded the estimates (95\% HPD interval boundaries) to the full million.

\section{Estimation of ancestral areas}

We conducted two kinds of biogeographical analyses (1) a likelihood method under DIVALIKE + J model (2) a Bayesian approach under the Bayesian Binary MCMC (BBM) method (Ronquist and Huelsenbeck, 2003) by the program RASP4 [64]. We defined the geographic areas based on established biogeographic and continental boundaries, such as the Red River fault between China and IndoChina Peninsula [41], the Isthmus of Kra between Indochina and the Malay Peninsula [65] and the Arakan Mountains between the Indian subcontinent and Indochina. These areas included: S-Sundaland and Sulawesi, I-India, DIndochina (Southwest of the Red River, including the southern part of China and excluding the part of Vietnam northeast of Red River), P-the Philippines, C-China (Northeast of the Red River and the part of Vietnam northeast of Red River), J-Japan (Fig. 2).

The DIVALIKE + J approach was conducted with the R-package "BioGeoBEARS" [66]. Firstly, we compared the six models adopted in the R-package "BioGeoBEARS" based on their AIC weight. Our ancestral range evolution analyses supported DIVALIKE $+\mathrm{J}$ as the model with the best fit to our data $(L n L=-80.48, A I C=167$, see Additional file 1: Table S3). We set the maximum number of areas of a species' range to three. For the BBM method, we set the maximum number of areas was three, and used F81 as the states frequencies, and set Gamma distribution as among-site rate variation. Other parameters are default. 
To investigate the natural history of insular P. leucomystax, we pruned the tree from BEAST maximum clade credibility tree and only left P. leucomystax samples with the R-package "Ape" [67], and applied the same DIVALIKE + J approach on it. The new defined geographic areas were: S-Sumatra, M-Malay Peninsula, B-Borneo, A-Java, P-the Philippines, J-Japan, W-Sulawesi (Fig. 3). Before the DIVALIKE + J analysis, we are grouping the samples with every clade and separated sample 85 from other samples in the same clade as one group, and sample 102, 103 from other samples in the same clade as one group additionally, then estimated the net evolutionary divergence between each group with MEGA7 [56] (Fig. 3). The result showed that the distance between group $\nabla$ and $\nabla$ were $0.01, \nabla$ and $\nabla$ were 0.004 (see Additional file 1: Table S4), therefore we considered the species in each clade as a cryptic lineages and continue the following DIVALIKE $+\mathrm{J}$ analysis.

\section{Declarations}

\section{Acknowledgements}

Here we would like to thank Yunyun Lv and Claudio Sabatelli for technical assistance and insightful comments and suggestions.

\section{Authors' contributions}

J-T.L. and D-C.J. conceived the study; X-L.D. and L-M.Y. performed data analyses; X-L.D., L-M.Y. and S.K. prepared the initial manuscript draft. All authors worked on the final manuscript.

\section{Funding}

This work was supported by the Strategic Priority Research Program of the Chinese Academy of Sciences (XDB31000000); the National Natural Science Foundation of China (31722049, 31772434, 31900322, 31911530101); Key Research Program of Frontier Sciences, CAS (QYZDB-SSW-SMC058); the Youth Innovation Promotion Association of CAS (2014338); Southeast Asia Biodiversity Research Institute (Y4ZK111B01); the CAS "Light of West China" Program (2018XBZG_JCTD_001); the Second Tibetan Plateau Scientific Expedition and Research Program (2019QZKK050); Russian Foundation of Basic Research (RFBR_GFEN 19-54-53010); and Innovative research project for postgraduates of Southwest Minzu university (CX2019SZ89).

\section{Availability of data and materials}

The datasets analysed during the current study are available in the GenBank repository, https://www.ncbi.nlm.nih.gov/

\section{Ethics approval and consent to participate}

This study was performed in accordance with the approval of Experimental Animal Ethics Committee of Chengdu Institute of Biology, Chinese Academy of Sciences. 


\section{Consent for publication}

Not applicable.

\section{Competing interests}

The authors declare that they have no competing interests.

\section{References}

1. Tschudi JJV, Seibert HC, Mertens R. Classification der Batrachier (mit Berücksichtigung der fossilen Thiere dieser Abtheilung der Reptilien). Society for the Study of Amphibians and Reptiles, (Publications secretary); 1838.

2. Frank N, Ramus E. A complete guide to scientific and common names of reptiles and amphibians of the world. NG Publishing Inc., Pottsville, Pennsylvania; 1995.

3. Amphibian Species of the Word 6.0, an Online Reference http://research.amnh.org/vz/herpetology/amphibia/_American Museum of Natural History, New York, USA.

4. Kuraishi N, Matsui M, Hamidy A, Belabut DM, Ahmad N, Panha S, Sudin A, Yong HS, Jiang JP, Ota H, et al. Phylogenetic and taxonomic relationships of the Polypedates leucomystax complex (Amphibia). Zool Scr. 2013;42:54-70.

5. Brown RM, Linkem CW, Siler CD, Sukumaran J, Esselstyn JA, Diesmos AC, Iskandar DT, Bickford D, Evans BJ, McGuire JA, et al. Phylogeography and historical demography of Polypedates leucomystax in the islands of Indonesia and the Philippines: evidence for recent human-mediated range expansion? Mol Phylogenet Evol. 2010;57:598-619.

6. Buddhachat K, Suwannapoom C. Phylogenetic relationships and genetic diversity of the Polypedates leucomystax complex in Thailand. PeerJ. 2018;6:e4263.

7. Narins PM, Feng AS, Yong HS, Christensen-Dalsgaard J. Morphological, behavioral, and genetic divergence of sympatric morphotypes of the treefrog Polypedates leucomystax in peninsular Malaysia. Herpetologica. 1998:129-142.

8. Pan SL, Dang NX, Wang JS, Zheng YT, Rao DQ, Li JT. Molecular Phylogeny Supports the Validity of Polypedates impresus Yang 2008. Asian Herpetol Res. 2013;4:124-133.

9. Trepanier TL, Lathrop A, Murphy RW. Rhacophorus leucomystax in Vietnam with acoustic analyses of courtship and territorial calls. Asiatic Herpetol Res. 1999;8:102-106.

10. Zhang P, Zhou H, Liang D, Liu YF, Chen YQ, Qu LH. The complete mitochondrial genome of a tree frog, Polypedates megacephalus (Amphibia: Anura: Rhacophoridae), and a novel gene organization in living amphibians. Gene. 2005;346:133-143.

11. Dutta SK, Manamendra-Arachchi K. The amphibian fauna of Sri Lanka. Wildlife Heritage Trust of Sri Lanka; 1996. 
12. Inger RF. Distribution of amphibians in southern Asia and adjacent islands. Patterns of distribution of amphibians: a global perspective. 1999:445-482.

13. Taylor EH. The amphibian fauna of Thailand. Univ Kansas Sci Bull. 1962;43:265-599.

14. Matsui M, Seto T, Utsunomiya T. Acoustic and karyotypic evidence for specific separation of Polypedates megacephalus from P. leucomystax. J Herpetol. 1986:483-489.

15. Kuraishi N, Matsui M, Ota H. Estimation of the Origin of Polypedates leucomystax (Amphibia: Anura: Rhacophoridae) Introduced to the Ryukyu Archipelago, Japan. Pac Sci. 2009;63:317-326.

16. Blair C, Davy CM, Ngo A, Orlov NL, Shi HT, Lu SQ, Gao L, Rao DQ, Murphy RW. Genealogy and Demographic History of a Widespread Amphibian throughout Indochina. J Hered. 2013;104:72-85.

17. Myers N, Mittermeier RA, Mittermeier CG, Da Fonseca GA, Kent J. Biodiversity hotspots for conservation priorities. Nature. 2000;403:853.

18. Li JT, Li Y, Klaus S, Rao DQ, Hillis DM, Zhang YP. Diversification of rhacophorid frogs provides evidence for accelerated faunal exchange between India and Eurasia during the Oligocene. Proc Natl Acad Sci USA. 2013;110:3441-3446.

19. Gonzalez P, Su YC, Siler CD, Barley AJ, Sanguila MB, Diesmos AC, Brown RM. Archipelago colonization by ecologically dissimilar amphibians: evaluating the expectation of common evolutionary history of geographical diffusion in co-distributed rainforest tree frogs in islands of Southeast Asia. Mol Phylogenet Evol. 2014;72:35-41.

20. Lohman DJ, de Bruyn M, Page T, von Rintelen K, Hall R, Ng PKL, Shih HT, Carvalho GR, von Rintelen T. Biogeography of the Indo-Australian Archipelago. Annu Rev Ecol Evol Syst. 2011;42:205-226.

21. Chen JM, Poyarkov NA, Jr., Suwannapoom C, Lathrop A, Wu YH, Zhou WW, Yuan ZY, Jin JQ, Chen $\mathrm{HM}$, Liu HQ, et al. Large-scale phylogenetic analyses provide insights into unrecognized diversity and historical biogeography of Asian leaf-litter frogs, genus Leptolalax (Anura: Megophryidae). Mol Phylogenet Evol. 2018;124:162-171.

22. Grismer LL, Wood PL, Aowphol A, Cota M, Grismer MS, Murdoch ML, Aguilar C, Grismer JL. Out of Borneo, again and again: biogeography of the Stream Toad genus Ansonia Stoliczka (Anura: Bufonidae) and the discovery of the first limestone cave-dwelling species. Biol J Linn Soc. 2016.

23. Hutter CR, Lambert SM, Andriampenomanana ZF, Glaw F, Vences M. Molecular phylogeny and diversification of Malagasy bright-eyed tree frogs (Mantellidae: Boophis). Mol Phylogenet Evol. 2018;127:568-578.

24. Lv Y-Y, He K, Klaus S, Brown RM, Li J-T. A comprehensive phylogeny of the genus Kurixalus (Rhacophoridae, Anura) sheds light on the geographical range evolution of frilled swamp treefrogs. Mol Phylogenet Evol. 2018;121:224-232.

25. O'Connell KA, Smart U, Smith EN, Hamidy A, Kurniawan N, Fujita MK. Within-island diversification underlies parachuting frog (Rhacophorus) species accumulation on the Sunda Shelf. J Biogeogr. 2018;45:929-940.

26. Pan T, Zhang Y, Wang H, Wu J, Kang X, Qian L, Chen J, Rao D, Jiang J, Zhang B. The reanalysis of biogeography of the Asian tree frog, Rhacophorus (Anura: Rhacophoridae): geographic shifts and 
climatic change influenced the dispersal process and diversification. PeerJ. 2017;5:e3995.

27. Yuan ZY, Zhang BL, J. C, Weisrock DW, Hime PM, Jin J-Q, Lemmon EM, Lemmon AR, Holland SD, Kortyna ML, et al. Natatanuran frogs used the Indian Plate to step-stone disperse and radiate across the Indian Ocean. Natl Sci Rev. 2019;6:10-14.

28. Meegaskumbura M, Meegaskumbura S, Bowatte G, Manamendra-Arachchi K, Pethiyagoda R, Hanken J, Schneider C. Taruga (Anura: Rhacophoridae), a new genus of foam-nesting tree frogs endemic to Sri Lanka. Ceylon J Sci (Biol Sci). 2011;39.

29. Klaus S, Morley RJ, Plath M, Zhang YP, Li JT. Biotic interchange between the Indian subcontinent and mainland Asia through time. Nat Commun. 2016;7:12132.

30. Gower DJ, Kupfer A, Oommen OV, Himstedt W, Nussbaum RA, Loader SP, Presswell B, Müller H, Krishna SB, Boistel R. A molecular phylogeny of ichthyophiid caecilians (Amphibia: Gymnophiona: Ichthyophiidae): out of India or out of South East Asia? Proceedings of the Royal Society of London Series B: Biological Sciences. 2002;269:1563-1569.

31. Klaus S, Schubart CD, Streit B, Pfenninger M. When Indian crabs were not yet Asian-biogeographic evidence for Eocene proximity of India and Southeast Asia. BMC Evol Biol. 2010;10:287.

32. Wilkinson M, Sheps JA, Oommen OV, Cohen BL. Phylogenetic relationships of Indian caecilians (Amphibia: Gymnophiona) inferred from mitochondrial rRNA gene sequences. Mol Phylogenet Evol. 2002;23:401-407.

33. Hughes AC, Satasook C, Bates PJJ, Bumrungsri S, Jones G. Explaining the causes of the zoogeographic transition around the Isthmus of Kra: using bats as a case study. J Biogeogr. 2011;38:2362-2372.

34. Hall R. The plate tectonics of Cenozoic SE Asia and the distribution of land and sea. Biogeography and geological evolution of SE Asia. 1998:99-131.

35. Replumaz A, Lacassin R, Tapponnier P, Leloup PH. Large river offsets and Plio-Quaternary dextral slip rate on the Red River fault (Yunnan, China). J Geophys Res Solid Earth. 2001;106:819-836.

36. Cheng WJ, Harrison TM, Lovera OM. Thermochronology of the Ailaoshan-Red River shear zone-A case study of multiple diffusion domain model. Seismol Geol. 1992;14:122-128.

37. Harrison TM, Chen WJ, Leloup PH, Ryerson FJ, Tapponnier P. An Early Miocene Transition in deformation regime within the Red River Fault Zone, Yunnan, And its significance for Indo-Asian tectonics. J Geophys Res. 1992;97.

38. Tang Y, Liu JL, Tran MD, Song ZJ, Wu WB, Zhang ZC, Zhao ZD, Chen W. Timing of left-lateral shearing along the Ailao Shan-Red River shear zone: constraints from zircon U-Pb ages from granitic rocks in the shear zone along the Ailao Shan Range, Western Yunnan, China. Int J Earth Sci. 2013;102:605-626.

39. Fan DM, Yue JP, Nie ZL, Li ZM, Comes HP, Sun H. Phylogeography of Sophora davidii (Leguminosae) across the 'Tanaka-Kaiyong Line', an important phytogeographic boundary in Southwest China. Mol Ecol. 2013;22:4270-4288. 
40. Zhang BL, Liu RX, Xiang HF, Wan JL, Huang XN. FT dating of fault rocks in the central-southern section of the Red River Fault zone and its geological implications. Seismol Geol. 2009;31:44-56.

41. Zhang DR, Chen MY, Murphy RW, Che J, Pang JF, Hu JS, Luo J, Wu SJ, Ye H, Zhang YP. Genealogy and palaeodrainage basins in Yunnan Province: phylogeography of the Yunnan spiny frog, Nanorana yunnanensis (Dicroglossidae). Mol Ecol. 2010;19:3406-3420.

42. Zhang MW, Rao DQ, Yang JX, Yu GH, Wilkinson JA. Molecular phylogeography and population structure of a mid-elevation montane frog Leptobrachium ailaonicum in a fragmented habitat of southwest China. Mol Phylogenet Evol. 2010;54:47-58.

43. Miller KG, Kominz MA, Browning JV, Wright JD, Mountain GS, Katz ME, Sugarman PJ, Cramer BS, Christie-Blick N, Pekar SF. The Phanerozoic record of global sea-level change. Science. 2005;310:1293-1298.

44. Voris HK. Maps of Pleistocene sea levels in Southeast Asia: shorelines, river systems and time durations. J Biogeogr. 2000;27:1153-1167.

45. Moss SJ, Wilson ME. Biogeographic implications of the Tertiary palaeogeographic evolution of Sulawesi and Borneo. Biogeography and geological evolution of SE Asia. 1998:133-163.

46. Klaus S, Selvandran S, Goh JW, Wowor D, Brandis D, Koller P, Schubart CD, Streit B, Meier R, Ng PKL, et al. Out of Borneo: Neogene diversification of Sundaic freshwater crabs (Crustacea: Brachyura: Gecarcinucidae:Parathelphusa). J Biogeogr. 2013;40:63-74.

47. Grosjean S, Ohler A, Chuaynkern Y, Cruaud C, Hassanin A. Improving biodiversity assessment of anuran amphibians using DNA barcoding of tadpoles. Case studies from Southeast Asia. C R Biol. 2015;338:351-361.

48. Haas A, Das I. Larval identities of Ansonia hanitschi Inger, 1960 (Amphibia: Bufonidae) and Polypedates colletti (Boulenger, 1890)(Amphibia: Rhacophoridae) from East Malaysia (Borneo). Salamandra. 2008;44:85-100.

49. Hasan M, Islam MM, Khan MMR, Igawa T, Alam MS, Djong HT, Kurniawan N, Joshy H, Sen YH, Belabut DM, et al. Genetic divergences of South and Southeast Asian frogs: a case study of several taxa based on $16 \mathrm{~S}$ ribosomal RNA gene data with notes on the generic name Fejervarya. Turk J Zool. 2014;38:389-411.

50. Hertwig ST, Schweizer M, Das I, Haas A. Diversification in a biodiversity hotspot--the evolution of Southeast Asian rhacophorid tree frogs on Borneo (Amphibia: Anura: Rhacophoridae). Mol Phylogenet Evol. 2013;68:567-581.

51. Li JT, Che J, Murphy RW, Zhao H, Zhao EM, Rao DQ, Zhang YP. New insights to the molecular phylogenetics and generic assessment in the Rhacophoridae (Amphibia: Anura) based on five nuclear and three mitochondrial genes, with comments on the evolution of reproduction. Mol Phylogenet Evol. 2009;53:509-522.

52. Matsui M, Hamidy A, Kuraishi N. A new species of Polypedates from Sumatra, Indonesia (Amphibia: anura). Species Divers. 2014;19:1-7. 
53. Matsui M, Shimada T, Sudin A. First record of the tree-frog genus Chiromantis from Borneo with the description of a new species (Amphibia: Rhacophoridae). Zool Sci. 2014;31:45-52.

54. Rujirawan A, Stuart BL, Aowphol A. A new tree frog in the genus Polypedates (Anura: Rhacophoridae) from southern Thailand. Zootaxa. 2013;3702:545-565.

55. Yu G, Rao D, Yang J, Zhang M. Phylogenetic relationships among Rhacophorinae (Rhacophoridae, Anura, Amphibia), with an emphasis on the Chinese species. Zool J Linn Soc. 2008;153:733-749.

56. Kumar S, Stecher G, Tamura K. MEGA7: Molecular Evolutionary Genetics Analysis Version 7.0 for Bigger Datasets. Mol Biol Evol. 2016;33:1870-1874.

57. Katoh K, Standley DM. MAFFT multiple sequence alignment software version 7: improvements in performance and usability. Mol Biol Evol. 2013;30:772-780.

58. Lanfear R, Frandsen PB, Wright AM, Senfeld T, Calcott B. PartitionFinder 2: New Methods for Selecting Partitioned Models of Evolution for Molecular and Morphological Phylogenetic Analyses. Mol Biol Evol. 2017;34:772-773.

59. Ronquist F, Teslenko M, van der Mark P, Ayres DL, Darling A, Hohna S, Larget B, Liu L, Suchard MA, Huelsenbeck JP. MrBayes 3.2: efficient Bayesian phylogenetic inference and model choice across a large model space. Syst Biol. 2012;61:539-542.

60. Stamatakis A. RAxML version 8: a tool for phylogenetic analysis and post-analysis of large phylogenies. Bioinformatics. 2014;30:1312-1313.

61. Bouckaert R, Vaughan TG, Barido-Sottani J, Duchêne S, Fourment M, Gavryushkina A, Heled J, Jones G, Kühnert D, De Maio N. BEAST 2.5: An advanced software platform for Bayesian evolutionary analysis. PLoS Comp Biol. 2019;15:e1006650.

62. Darriba D, Taboada GL, Doallo R, Posada D. jModelTest 2: more models, new heuristics and parallel computing. Nat Methods. 2012;9:772.

63. Rambaut A, Suchard MA, Xie D, Drummond AJ. Tracer v1. 6. Computer program and documentation distributed by the author. Retrieved from http://beast. bio. ed. ac. uk/Tracer; 2014.

64. Yu Y, Harris AJ, Blair C, He XJ. RASP (Reconstruct Ancestral State in Phylogenies): a tool for historical biogeography. Mol Phylogenet Evol. 2015;87:46-49.

65. Woodruff DS. Biogeography and conservation in Southeast Asia: how 2.7 million years of repeated environmental fluctuations affect today's patterns and the future of the remaining refugial-phase biodiversity. Biodivers Conserv. 2010;19:919-941.

66. Matzke NJ. BioGeoBEARS: BioGeography with Bayesian (and likelihood) evolutionary analysis in R Scripts. 2013:2013.

67. Paradis E, Claude J, Strimmer K. APE: analyses of phylogenetics and evolution in R language. Bioinformatics. 2004;20:289-290.

\section{Figures}




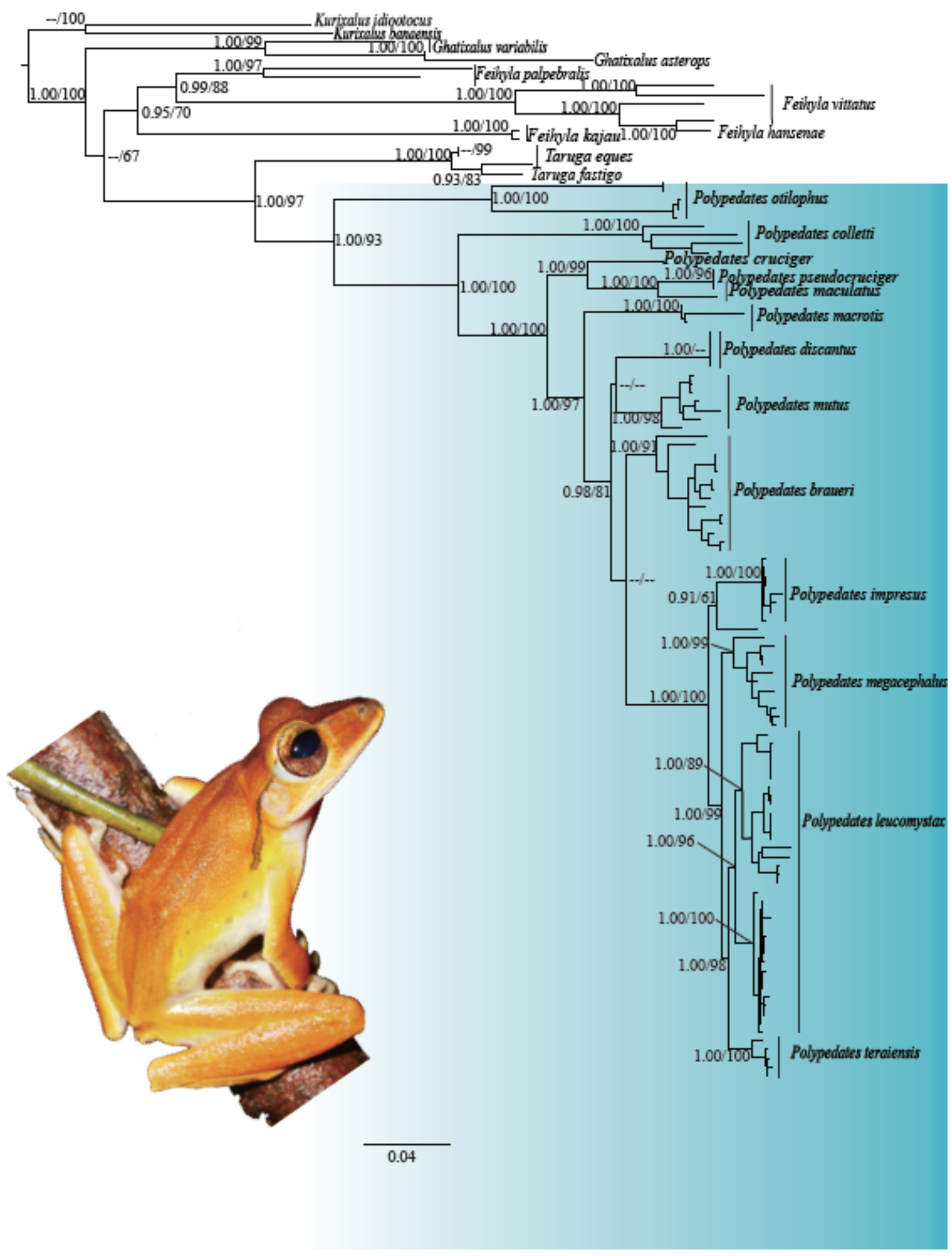

\section{Figure 1}

Phylogenetic tree inferred from mitochondrial and nuclear DNA. Numbers above the lines or besides the nodes are given as Bayesian posterior probabilities (BPP) /bootstrap support (BSP) for maximum likelihood analyses; '-' represents BPP and BSP lower than 0.9 and 50, respectively. 


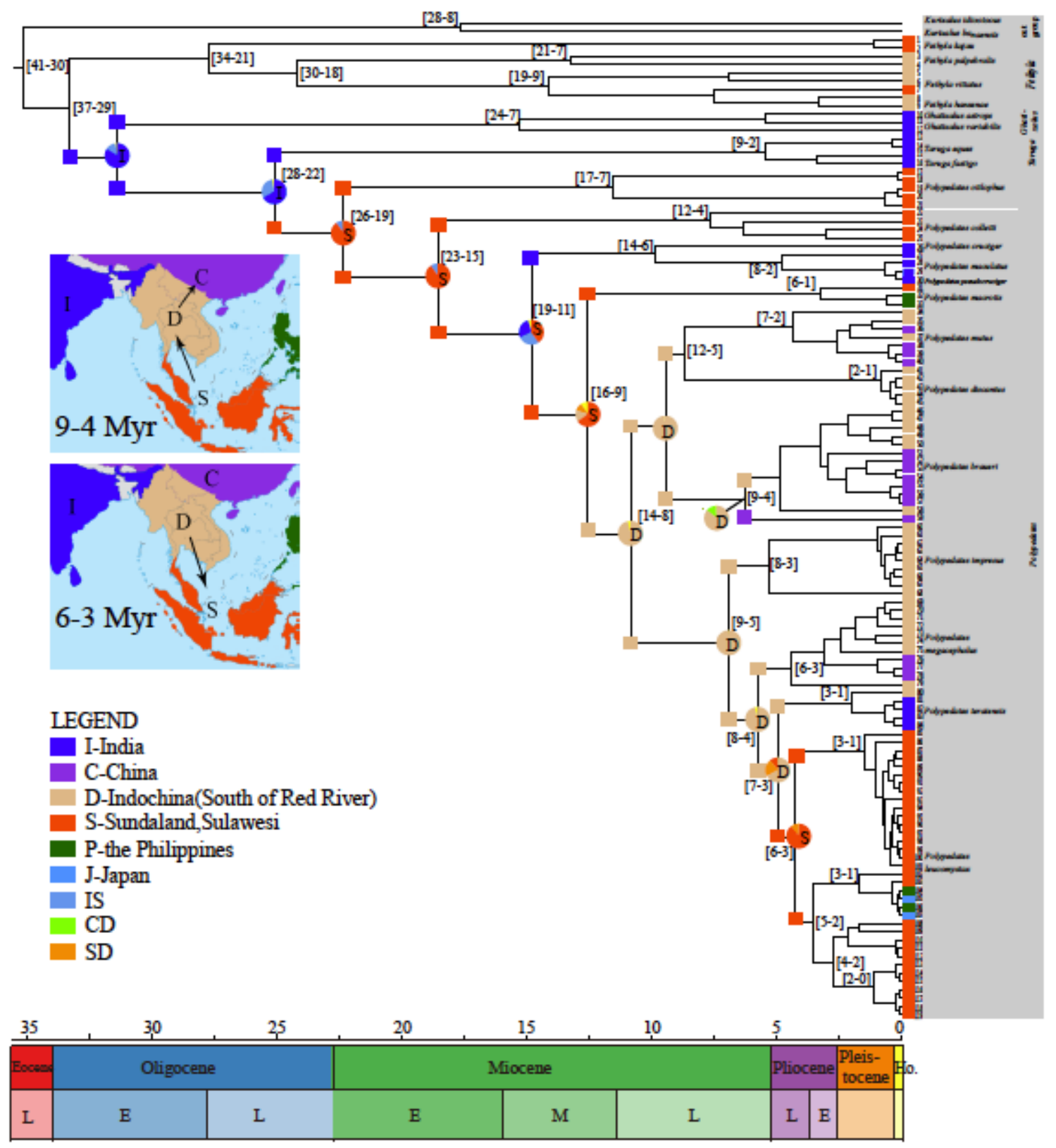

Figure 2

Estimation of ancestral areas for the genus Polypedates and its three closest related genera based on a Bayesian maximum clade credibility tree. The square labels on the tree are range estimates according to the DIVALIKE+J model, and the pie charts represent the posterior probability of ancestral ranges according to Bayesian Binary MCMC. The numbers in the phylogenetic tree tip are consistent with the numbers of the species in Supplement Table S1. Note: The designations employed and the presentation of the material on this map do not imply the expression of any opinion whatsoever on the part of Research Square concerning the legal status of any country, territory, city or area or of its authorities, or concerning the delimitation of its frontiers or boundaries. This map has been provided by the authors. 


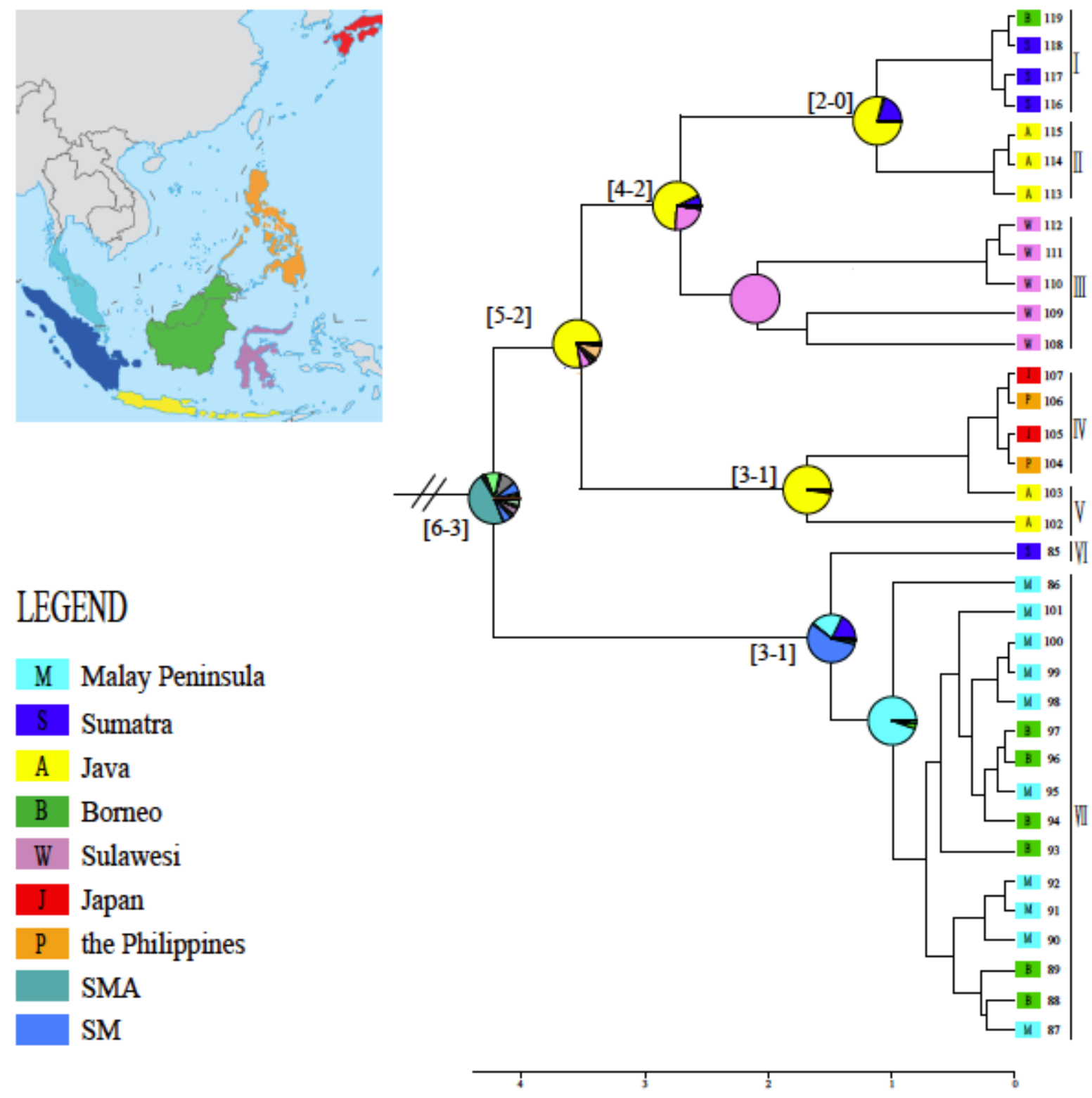

Figure 3

Estimation of ancestral areas for the species Polypedates leucomystax based on the Bayesian maximum clade credibility tree given in Fig. 2. 95\% credibility interval of the time estimates was given in square brackets. The square labels on the tree are range estimates according to the DIVALIKE+J model. The Roman numerals are used for the group distance estimation. Note: The designations employed and the presentation of the material on this map do not imply the expression of any opinion whatsoever on the part of Research Square concerning the legal status of any country, territory, city or area or of its authorities, or concerning the delimitation of its frontiers or boundaries. This map has been provided by the authors. 


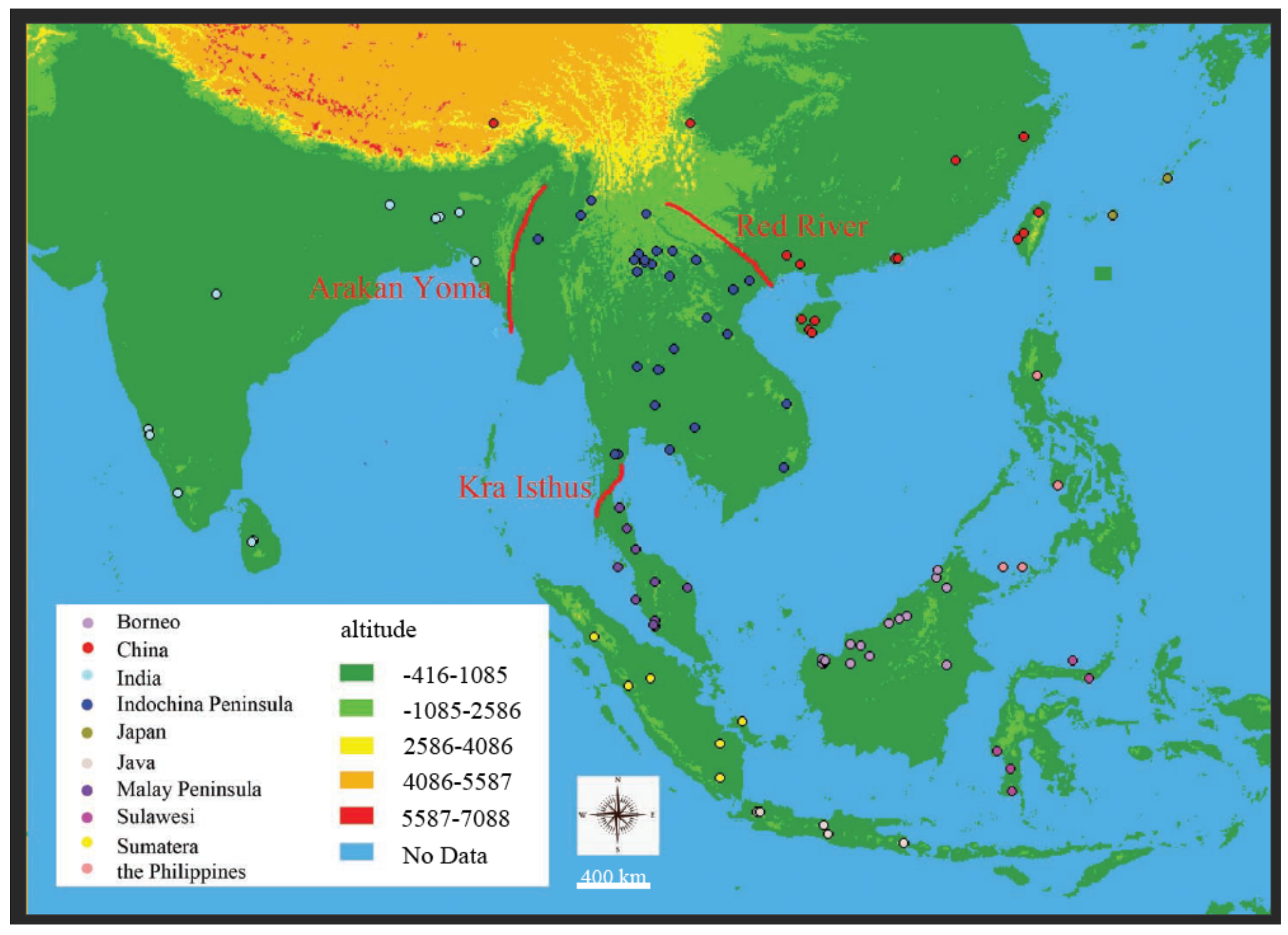

\section{Figure 4}

Collection sites of species in this study. Note: The designations employed and the presentation of the material on this map do not imply the expression of any opinion whatsoever on the part of Research Square concerning the legal status of any country, territory, city or area or of its authorities, or concerning the delimitation of its frontiers or boundaries. This map has been provided by the authors.

\section{Supplementary Files}

This is a list of supplementary files associated with this preprint. Click to download.

- Additionalfile1.SupplementaryTablesandFigures.docx 